\title{
9. PALEOGENE PLANKTONIC FORAMINIFERS FROM DEEP SEA DRILLING PROJECT LEG 62 SITES AND ADJACENT AREAS OF THE NORTHWEST PACIFIC ${ }^{1}$
}

\author{
Valery A. Krasheninnikov, Geological Institute of the U.S.S.R. Academy of Sciences, Moscow, U.S.S.R.
}

\begin{abstract}
Paleogene carbonate sediments, with planktonic foraminifers, of the western Mid-Pacific Mountains (Deep Sea Drilling Project Site 463) and Hess Rise (Sites 465 and 466) contain numerous hiatuses. Materials of previous DSDP legs (Sites 44, 47, 171, 192, 305, 310, 313) were used to expand knowledge of the Paleogene stratigraphy of the northwest Pacific and to construct a zonal stratigraphy of Paleogene deposits for this region based on planktonic foraminifers.
\end{abstract}

\section{INTRODUCTION}

Before the beginning of deep-sea drilling, the character of Paleogene planktonic foraminifers of the northwest Pacific was poorly known, because the Paleogene of Japan is composed of geosynclinal terrigenous and volcanogenic sediments containing poor assemblages of planktonic foraminifers, and in the U.S.S.R. (Kamchatka Peninsula, Sakhalin Island) geosynclinal terrigenous facies are also characteristic of the Paleogene; the poverty of planktonic foraminifers therein may be related to location in high latitudes $\left(50-60^{\circ}\right)$.

Deep-sea drilling in the northwest Pacific changed this situation. As early as DSDP Leg 6 (1969), Paleogene calcareous sediments were penetrated on Shatsky Rise (Site 47; Paleocene to lower Eocene) and on Horizon Guyot (Site 44; middle to upper Eocene and Oligocene) (Krasheninnikov, 1971a, b). On Leg 17, again on Horizon Guyot (Site 171), middle Eocene and Oligocene deposits were identified (Douglas, 1973); on Leg 19, at the northwest end of the Emperor Seamounts (Site 192), Eocene and Oligocene sediments were discovered (Echols, 1973); on Leg 32, Paleocene, Eocene, and Oligocene sediments were found on Shatsky Rise (Site 305), and lower and middle Eocene and Oligocene sediments were found on Hess Rise (Site 310) and in the eastern Mid-Pacific Mountains (Site 313) (Luterbacher, 1975; Toumarkine, 1975; Fleisher, 1975). Finally, on Leg 62 lower and middle Eocene and Oligocene sediments were penetrated in the western Mid-Pacific Mountains (Site 463), and Paleocene and middle Eocene sediments were penetrated on Hess Rise (Sites 465 and 466). Unfortunately, all of these sections are stratigraphically incomplete and are commonly marked by one or more hiatuses. Where the sections are continuous (Site 47, for instance), they represent only part of the Paleogene.

Through the courtesy of the Deep Sea Drilling Project, the author received samples of Paleogene sediments from Leg 17 (Site 171), Leg 19 (Site 192), and Leg 32

\footnotetext{
${ }^{1}$ Initial Reports of the Deep Sea Drilling Project, Volume 62.
}

(Sites $305,310,313$ ). The combination of data on the stratigraphy of Paleogene sediments from Legs 6,17 , 19,32 , and 62 permits recognition of the main peculiarities of planktonic-foraminifer assemblages and $\mathrm{Pa}$ leogene zonal stratigraphy of the northwest Pacific. Subdivision of the Paleogene sediments follows the zonal scheme of Bolli (1957a, b), with some modifications (Blow 1969; Premoli-Silva and Bolli, 1973). Information is presented here in correspondence with descending latitude, from the northern sections (Emperor Seamounts) to the southern ones (Mid-Pacific Mountains).

\section{STRATIGRAPHY OF PALEOGENE SEDIMENTS AT THE SITES}

In the northwest Pacific Ocean, Paleogene carbonate sediments containing planktonic foraminifers are present between $53^{\circ}$ and $19^{\circ}$ north latitude.

\section{The Emperor Seamounts}

The most northern hole is 192A, on the top of Meiji Guyot, at the northwest end of the Emperor Seamounts $\left(53^{\circ} 00.57^{\prime} \mathrm{N}, 164^{\circ} 42.81^{\prime} \mathrm{E}\right.$; water depth $\left.3014 \mathrm{~m}\right)$. In this hole the middle Maastrichtian nannofossil chalk is unconformably overlain by about 85 meters of gray to white nannofossil chalk and dark-gray calcareous and nannofossil-rich claystone, the lower part of which (Sample 192A-4-3, 124-126 cm to Sample 192A-4-4, $120-122 \mathrm{~cm}$ ) is characterized by rare, small Acarinina pentacamerata, $A$. interposita, $A$. pseudotopilensis, $A$. sp. aff. A. soldadoensis, A. sp., Globigerina senni, $G$. eocaenica, and $G$. sp. aff. G. pseudoeocaena and is assigned to the lower Eocene. Overlying sediments (Sample 192A-1-4, 50-52 cm to Sample 192A-4-3, 30-32 $\mathrm{cm})$ contain only sporadic, small Pseudohastigerina micra, Globigerina sp. aff. G. pseudoeocaena, and $G$. sp., and can be assigned to the middle-upper Eocene. At the top of this sequence (Sample 192A-1-2, 50-52 $\mathrm{cm}$ ), the planktonic-foraminifer assemblage is somewhat more diverse, containing Globigerinita unicava, Globorotaloides suteri, Globigerina praebulloides, G. ouachitaensis, G. angiporoides, and Globorotalia permicra. Joint occurrence of the two last species shows 
that the sediments belong to the uppermost upper Eocene to lower Oligocene. The nannofossil chalk is overlain by gray and greenish claystones (Hole 192), devoid of organic remains, and the age is thus unclear.

Unfortunately, the lower Eocene to lower Oligocene planktonic foraminifers are poorly preserved, and their precise identification is difficult.

\section{Hess Rise}

Site $310\left(36^{\circ} 52.11^{\prime} \mathrm{N}, 176^{\circ} 54.09^{\prime} \mathrm{E}\right.$; water depth 3516 $\mathrm{m})$ provided scant information on the biostratigraphy of Paleogene sediments.

Maastrichtian nannofossil ooze is unconformably overlain by zeolitic nannofossil ooze and nannofossilbearing zeolitic pelagic clay of the uppermost lower Eocene to the basal middle Eocene. Planktonic foraminifers were subjected to strong selective dissolution, and are represented by single or rare Globigerina senni, G. pseudoeocaena, G. higginsi, G. sp., Acarinina pseudotopilensis, and $A$. sp. aff. $A$. bullbrooki (Sample 310-11-1, 122-124 cm to Sample 310-11-5, 100-102 cm).

Higher in the section are lower Oligocene nannofossil oozes with a hiatus. They contain richer assemblages of planktonic foraminifers: Globigerina prasaepsis, G. tapuriensis, G. galavisi, G. corpulenta, G. praebulloides, G. angiporoides, G. gortanii, Globigerinita unicava, $G$. riveroae, G. pera, Globorotaloides suteri, Globorotalia permicra, and G. gemma (Sample 310-10-1, 100-102 cm to Sample $310-10-6,20-22 \mathrm{~cm})$. This microfauna enables us to attribute the sediments to the Globigerina tapuriensis Zone, but it must be borne in mind that some index species may have been destroyed by selective dissolution. Dissolution is extremely pronounced, and, although unbroken tests are present, many are fragmented.

At this site, Paleogene deposits are 19-meters thick and are overlain unconformably by middle Miocene deposits.

The investigations of Leg 62 produced important new information on the stratigraphy and geological history of Hess Rise. A complete Paleocene section was penetrated at Site 465 , and middle Eocene sediments were recognized at Site 466.

At Site $465\left(33^{\circ} 49.23^{\prime} \mathrm{N}, 178^{\circ} 55.14^{\prime} \mathrm{E}\right.$; water depth $2161 \mathrm{~m}$ ) the Upper Cretaceous (Maastrichtian, $A b a-$ thomphalus mayaroensis Zone) passes into the Paleogene by a gradual transition. The Paleogene is represented by Paleocene deposits unconformably overlain by Pliocene deposits. The Paleocene is composed of nannofossil ooze and foraminifer-nannofossil ooze with interbeds of gray chert; the thickness is 54 meters. The Paleocene is subdivided into the following zones by means of planktonic foraminifers.

The Globigerina eugubina Zone was recognized at $465 \mathrm{~A}-3-3$, but no samples from this interval were at the author's disposal.

The Globigerina pseudobulloides Zone (Globigerina taurica Zone or Globigerina eobulloides Zone according to various zonal schemes) contains great numbers of Guembelitria irregularis and Chiloguembelina taurica, and rarer Globigerina eobulloides, G. tetragona, $G$. fringa, and Globorotalia sp. aff. G. pseudobulloides (Sample 465A-3-2, 90-92 cm).

The Globorotalia trinidadensis Zone contains numerous specimens of the index species, and G. pseudobulloides; Chiloguembelina taurica, Globigerina trivialis, and Globorotalia compressa are common, whereas Globigerina varianta, G. edita, and Guembelitria irregularis are rare (Sample 465A-3-1, 90-92 cm). Sample $465-8, C C$ likely belongs to the same zone; its assemblage of planktonic foraminifers consists of rare Globorotalia trinidadensis and $G$. pseudobulloides.

The three above-mentioned zones constitute the Danian Stage in the strict sense.

The Acarinina uncinata Zone, with numerous $A$. uncinata, $A$. praecursoria, and $A$. inconstans, accompanied by Globorotalia pseudobulloides, G. compressa, Chiloguembelina taurica, Ch. sp., and rarer Acarinina spiralis, Globigerina varianta and G. trivialis (Sample $465-7, C C)$, together with the three aforementioned zones constitutes the Danian Stage in the broad sense.

The Globorotalia angulata Zone in the strict sense has not been recognized at Site 465; presumably, its absence is related to poor recovery; only one sample (465-7,CC) was taken in which the Acarinina uncinata Zone was recognizable.

The Globorotalia conicotruncata Zone (or the Globorotalia pusilla Zone), with abundant G. conicotruncata, accompanied by $G$. pusilla, G. cubanensis, G. angulata, and G. ehrenbergi, rarer G. quadrata, Globigerina varianta, $G$. trivialis, Acarinina tadjikistanensis djanensis, and sporadic Globigerina triloculinoides, is present from Sample 465-6-1, 90-92 cm to Sample 4656-5, 90-92 cm. In Sample 465-6-1, 90-92 cm, a transition to sediments of the Globorotalia pseudomenardii Zone is observed. Here are specimens of highly specialized Globorotalia conicotruncata, characterized by large dimensions, a great number of chambers (8-10), ornamented umbilical end of the chambers, and an even peripheral margin with a thin, distinct keel; they are accompanied by rare specimens of Globorotalia occlusa, Globigerina nana, and $G$. velascoensis, which become more abundant in the overlying sediments.

The Globorotalia pseudomenardii Zone contains extremely rare specimens of the index species, abundant Globorotalia velascoensis, G. occlusa, G. laevigata, and G. convexa, and rarer Globorotalia pasionensis, G. imitata, Globigerina nana, G. velascoensis, and G. quadritriloculinoides. The upper part of the zone contains abundant Acarinina mckannai and $A$. aquiensis, and sporadic specimens of $A$. acarinata. In Hole $465 A$, this zone includes Sample 465A-1-1, 90-92 cm; it should be attributed to the very base of the Globorotalia pseudomenardii Zone, because in its assemblage of planktonic foraminifers rather abundant Globorotalia conicotruncata are still present. In Hole 465, this zone corresponds to the interval from Sample 465-4-2, 90-92 cm to Sample $465-5-6,30-32 \mathrm{~cm}$. The first of these samples contains rare specimens of Acarinina acarinata, $A$. soldadoensis, A. esnaensis, Globorotalia acuta, G. aequa, and $G$. hispidicidaris (transition to the Globorotalia velascoensis Zone). In the second sample, rare speci- 
mens of Globorotalia conicotruncata were recognized, which indicate a transition to the Globorotalia conicotruncata Zone.

The Globorotalia velascoensis Zone, with $G$. velascoensis, G. occlusa, G. acuta, G. aequa, G. convexa, G. hispidicidaris, G. pasionensis, G. imitata, Acarinina acarinata, $A$. soldadoensis, $A$. primitiva, $A$. esnaensis, A. mckannai, Globigerina velascoensis, G. nana, G. quadritriloculinoides, and $G$. compressaformis, is present from Sample 465-3-1, 90-92 cm to Sample 465-4-1, 90-92 cm.

At Site $466\left(34^{\circ} 11.46^{\prime} \mathrm{N}, 179^{\circ} 15.34^{\prime} \mathrm{E}\right.$; water depth $2665 \mathrm{~m}$ ), the Paleogene section is markedly different: neither Paleocene or lower Eocene sediments are present. Instead, upper Campanian to lower Maastrichtian deposits are directly overlain by about 23 meters of middle and upper Eocene nannofossil oozes, with chert interbeds in the lower part.

In the basal layers of the middle Eocene, the planktonic-foraminifer assemblage consists of Acarinina bullbrooki, A. pentacamerata, A. aspensis, A. triplex, Globorotalia aragonensis, G. caucasica, G. marksi, Globigerina pseudoeocaena, and G. senni (Sample $466-9-4,90-92 \mathrm{~cm}$ to Sample 466-10,CC). Higher in the section (Sample 466-9-1, 90-92 cm to Sample 466-9-3, $90-92 \mathrm{~cm}$ ), the same species persist, but specimens of Acarinina bullbrooki are abundant, and Globorotalia boweri appears as well. These sediments are assigned to the base of the middle Eocene (Hantkenina aragonensis Zone in the broad sense). Along with the middle Eocene microfauna, numerous redeposited planktonic foraminifers of the Upper Cretaceous and rare ones of the upper Paleocene are identified.

The sediments from Sample 466-8-1, 90-92 cm to Sample 466-8-6, 90-92 cm were conditionally attributed to the Eocene; only rare benthic foraminifers were recovered here. In Sample 466-7-7, 20-22 cm, the planktonic-foraminifer assemblage consists of an admixture of Upper Cretaceous, lower and middle Eocene (Globorotalia caucasica, G. aragonensis, Acarinina bullbrooki, A. rotundimarginata, Globigerapsis index, and G. kugleri), and Oligocene (Globigerina sellii) species. These carbonate turbidites are likely younger (late Oligocene to Neogene). They are overlain by lower Pliocene sediments.

\section{Shatsky Rise}

The best Paleogene sections in the northwest Pacific appear to be on Shatsky Rise (Sites 47 and 305).

Site 47 is on the northwest slope of the rise $\left(32^{\circ}\right.$ $26.09^{\prime} \mathrm{N}, 157^{\circ} 42.07^{\prime} \mathrm{E}$; water depth $\left.2689 \mathrm{~m}\right)$. Here, nannofossil and foraminifer-nannofossil chalk and oozes of the Paleocene, lower Eocene, and lowermost middle Eocene rest conformably on the Upper Cretaceous (Maastrichtian, Abathomphalus mayaroensis Zone), and are unconformably overlain by upper Miocene sediments. Their thickness is insignificant, about 44 meters. The excellently preserved planktonic foraminifers record the entire succession of Paleocene and lower Eocene zones, testifying to continuity of the section. Unfortunately, the sediments were strongly deformed by drilling, and in places they were soupy. This makes exact definition of the stratigraphic boundaries difficult, a fact disregarded by some authors studying foraminifers from Site 47 (for instance, Hofker, 1978). Of the three holes drilled at Site 47 , Hole 47.2 proved most successful and will be discussed below.

In the interval from Sample 47.2-11-4, 10-12 cm to Sample 47.2-11-6, 145-147 cm, the planktonic foraminifer assemblages are a mixture of Maastrichtian and Danian species (Acarinina uncinata Zone); sometimes they are accompanied by upper Paleocene species (the thickness of sediments deformed by drilling is not less than $4.5 \mathrm{~m})$. Globigerina eugubina, G. minutula, G. sabina, and G. trifolia, observed here with abundant Chiloguembelina and Guembelitria, suggest that the Danian Stage begins with the Globigerina eugubina Zone.

The Globigerina taurica Zone (or the Globigerina pseudobulloides Zone) includes sediments with abundant Chiloguembelina taurica, C. morsei, C. midwayensis, and Guembelitria irregularis, accompanied by Globigerina daubjergensis, G. taurica, G. eobulloides, $G$. tetragona, G. pentagona, G. fringa, G. theodosica, G. hemisphaerica, and Globorotalia sp. aff. G. pseudobulloides (Sample 47.2-11-3, 145-147 cm). Mechanical admixture of Maastrichtian forms is not great here. The observed specimens of Globigerina sabina and G. minutula are probably components of the paleocoenosis of foraminifers of this zone.

The Globorotalia trinidadensis Zone is characterized by numerous specimens of the index species, G. pseudobulloides, Globigerina daubjergensis, Chiloguembelina midwayensis, C. taurica, C. morsei, and Guembelitria irregularis, and rarer Globorotalia compressa, Globigerina trivialis, G. varianta, and G. edita; Globigerina triloculinoides and Globorotalia planocompressa are sporadic (47.2-11 (top) to Sample 47.2-11-3, 10-12 cm).

An extremely rich assemblage of planktonic foraminifers of the Acarinina uncinata Zone consists of $A$. uncinata, $A$. inconstans, $A$. indolensis, $A$. spiralis, $A$. praecursoria, $A$. schachdagica, A. multiloculata, Globorotalia pseudobulloides, G. compressa, G. quadrata, Globigerina trivialis, G. varianta, and $G$. triloculinoides; representatives of heterohelicids are rare (Sample 47.2-10-4, 120-122 cm to Sample 47.2-10,CC).

The Globorotalia angulata Zone in the strict sense contains numerous $G$. angulata and rare G. ehrenbergi; they are accompanied by Acarinina multiloculata, Globorotalia quadrata, G. pseudobulloides, Globigerina varianta, G. trivialis, and G. triloculinoides (Sample $47.2-10-3,110-112 \mathrm{~cm}$ to Sample 47.2-10-4, 80-82 cm). The exact positions of the lower and upper boundaries of this zone are obscure, because of deformation of sediments by drilling.

The Globorotalia conicotruncata Zone contains the index species, G. pusilla, G. cubanensis, and Acarinina tadjikistanensis djanensis, associated with Globorotalia angulata, G. ehrenbergi, Globigerina varianta, and $G$. trivialis (47.2-10 (top) to Sample 47.2-10-3, 1-3 cm).

The Globorotalia pseudomenardii Zone contains the index species in abundance, associated with $G$. velascoensis, G. occlusa, G. pasionensis, G. laevigata, G. con- 
vexa, G. imitata, Acarinina mckannai, Globigerina velascoensis, G. nana, G. bacuana, G. quadritriloculinoides, and $G$. pileata (Sample 47.2-8-5, 114-115 cm to Sample 47.2-9,CC).

The Globorotalia velascoensis Zone contains an extremely diverse assemblage of planktonic foraminifers: $G$. velascoensis, G. pasionensis, G. occlusa, G. aequa, $G$. acuta, G. hispidicidaris, G. apanthesma, G. trichotrocha, G. parva, G. tortiva, G. imitata, Acarinina acarinata, $A$. esnaensis, $A$. soldadoensis, $A$. primitiva, A. mckannai, A. tribulosa, Globigerina nana, G. velascoensis, G. chascanona, and G. compressaformis (Sample $47.2-8-4,73-75 \mathrm{~cm}$ to Sample $47.2-8-5,66-68 \mathrm{~cm}$ ).

It is also difficult to define the exact position of the Paleocene/Eocene boundary, because of mechanical deformation of sediments by drilling (within $1.5 \mathrm{~m}$ ). However, the succession of zonal assemblages of planktonic foraminifers in the lower Eocene is perfectly distinct. The following zones are distinguished:

The Globorotalia subbotinae Zone contains the index species and $G$. aequa, G. wilcoxensis, G. quetra, $G$. elongata, Acarinina pseudotopilensis, A. camerata, $A$. triplex, $A$. esnaensis, $A$. soldadoensis, $A$. gravelli, $A$. primitiva, Globigerina compressaformis, G. prolata, and $G$. collactea; specimens of Pseudohastigerina wilcoxensis are sporadic. In the upper part of the zone are Globorotalia marginodentata, G. formosa gracilis, and Acarinina broedermanni (Sample 47.2-8-3, $81-82 \mathrm{~cm}$ to Sample 47.2-8-4, 23-25 cm).

The Globorotalia formosa formosa Zone contains the index taxon, $G$. formosa gracilis, $G$. lensiformis, $G$. marginodentata, G. quetra, G. wilcoxensis, G. naussi, Acarinina decepta, and Heterohelix wilcoxensis. Acarinina pseudotopilensis, $A$. triplex, A. broedermanni, $A$. gravelli, $A$. soldadoensis, Globigerina compressafor$m i s$, and $G$. prolata are common ranging up from the underlying deposits (47.2-8 (top) to Sample 47.2-8-3, 30-32 cm).

The Globorotalia aragonensis Zone has numerous specimens of the index species, accompanied by $G$. marksi, Acarinina interposita, A. pentacamerata, Globigerina eocaenica, G. pseudoeocaena, G. inaequispira, and rare Globorotalia caucasica. Still present here are Acarinina triplex, A. pseudotopilensis, A. broedermanni, A. decepta, A. soldadoensis, A. gravelli, Pseudohastigerina wilcoxensis, and Globorotalia quetra, with comparatively rare $G$. lensiformis and $G$. formosa formosa (Sample 47.2-7-5, 25-27 cm to Sample 47.27,CC).

The Globorotalia palmerae Zone (or the Acarinina pentacamerata Zone) is characterized by abundant $A$. pentacamerata, A. aspensis, Globigerina senni, and Globorotalia caucasica. Other species are Globorotalia planoconica, G. aragonensis, G. marksi, G. naussi, Globigerina higginsi, G. pseudoeocaena, G. inaequispira, G. turgida, G. taroubaensis, G. prolata, G. eocaena, Acarinina interposita, A. triplex, A. pseudotopilensis, $A$. soldadoensis, $A$. broedermanni, and Pseudohastigerina wilcoxensis (Sample 47.2-7-2, 128-130 cm to Sample 47.2-7-4, 110-112 cm).
The basal middle Eocene is represented by the Hantkenina aragonensis Zone in the broad sense, with numerous Acarinina bullbrooki, A. pentacamerata, $A$. aspensis, and Globorotalia caucasica, along with Globorotalia boweri, G. spinulosa, G. renzi, G. aragonensis, Globigerina senni, G. pseudoeocaena, and Pseudohastigerina micra (Samples 47.2-7-2, 85-87 $\mathrm{cm}$ and 47.2-7-2, 23-25 cm). Younger sediments of the middle Eocene were eliminated by underwater erosion, evidenced by redeposited Globigerapsis index, Globigerinatheca barri, and Truncorotaloides topilensis in the basal deposits of the upper Miocene.

Site 305 is on the southwest slope of Shatsky Rise $\left(32^{\circ} 00.13^{\prime} \mathrm{N}, 157^{\circ} 51.00^{\prime} \mathrm{E}\right.$; water depth $\left.2903 \mathrm{~m}\right)$. Although the distance from Site 47 is insignificant, and the water depth is only 214 meters more, the Paleogene deposits and planktonic foraminifers are very different here. The Paleogene is represented by monotonously uniform foraminifer-nannofossil ooze, 76 meters thick, separated from the Upper Cretaceous (Maastrichtian, Abathomphalus mayaroensis Zone) by a hiatus.

The Paleocene begins with the Globorotalia conicotruncata Zone, in which common specimens of the index species are accompanied by rare $G$. pusilla and $G$. angulata (Samples 305-14-4, 120-122 cm and 305-14-5, $120-122 \mathrm{~cm})$. Thus, the section is devoid of five zones from the Globigerina eugubina Zone to the Globorotalia angulata Zone in the strict sense. From the data of Luterbacher (1975), who found in Sample 305-14,CC pieces of sediments with foraminifer assemblages of the Globorotalia trinidadensis, Acarinina uncinata, and Globorotalia angulata Zones, it would appear that the sediments bearing these forms have been destroyed by underwater erosion.

The Globorotalia pseudomenardii Zone is characterized by abundant Acarinina mckannai, associated with rare Globorotalia occlusa and $G$. trichotrocha, and extremely rare $G$. velascoensis, $G$. pseudomenardii, and Globigerina velascoensis (Sample 305-13-6, 120-122 cm to Sample 305-14-3, 120-122 cm).

The Globorotalia velascoensis Zone contains abundant Acarinina acarinata, accompanied by $A$. primitiva, A. soldadoensis, A. esnaensis, A. mckannai, and very rare Globorotalia acuta, G. aequa, G. velascoensis, and G. occlusa, (Sample 305-13-1, 118-120 cm to Sample 305-13-5, 117-119 cm).

Paleocene assemblages of planktonic foraminifers of Site 305 underwent strong selective dissolution: many species of keeled Globorotalia were destroyed by dissolution; tests of the remaining planktonic foraminifers have an etched surface; there are numerous fragments of planktonic foraminifers; and the foraminifer assemblages are enriched in benthic forms. As a result of these subsequent changes, the assemblages of Paleocene planktonic foraminifers at Site $\mathbf{3 0 5}$ differ sharply from those at Site 47 , displaying considerable similarity to the natural subtropical-temperate assemblages of Paleocene planktonic foraminifers of the northern Caucasus. Here, biostratigraphic units synchronous with the Globorotalia pseudomenardii and Globorotalia velascoen- 
sis Zones bear the names Acarinina subsphaerica (synonym of $A$. mckannai) and Acarinina acarinata Zones. The Paleocene acarininids, which reached their peak in the subtropical and temperate climatic belts, are highly resistant to selective dissolution.

The Eocene is separated from the Paleocene by a hiatus, as indicated by the absence of the Globorotalia subbotinae Zone.

In the lower Eocene, the assemblages of planktonic foraminifers are as rich as at Site 47 , although the features of selective dissolution are rather obvious here as well. The following zones are identified:

The Globorotalia formosa formosa Zone, with numerous specimens of the index species, G. lensiformis, G. formosa gracilis, Acarinina pseudotopilensis, A. esnaensis, $A$. gravelli, $A$. acarinata, $A$. triplex, $A$. soldadoensis, and $A$. camerata (Sample 305-12-1, 125-127 cm to Sample 305-12-5, 126-128 cm);

The Globorotalia aragonensis Zone contains the index species, $G$. lensiformis, Acarinina interposita, $A$. soldadoensis, A. triplex, $A$. pseudotopilensis, and rare A. pentacamerata (Samples 305-11-5, 120-122 cm and 305-11-6, 130-132 cm);

The Globorotalia palmerae Zone (or the Acarinina pentacamerata Zone) contains numerous $A$. pentacamerata, $A$. aspensis, and $A$. interposita, in association with rarer Globorotalia aragonensis, Globigerina senni, G. higginsi, G. pseudoeocaena, Acarinina pseudotopilensis, and A. triplex, and sporadic Globorotalia caucasica (Sample 305-11-1, 94-96 cm to Sample 305-11-4, $130-132 \mathrm{~cm})$.

Selective dissolution heavily affected planktonic foraminifers of the middle and upper Eocene and Oligocene, making zonation of these deposits difficult.

The middle Eocene includes rare Globigerapsis index, Globigerinatheca barri, Acarinina bullbrooki, Truncorotaloides topilensis, $T$. rohri, Globigerina senni, $G$. pseudoeocaena, and Globorotalia spinulosa (Sample $305-10-4,22-24 \mathrm{~cm}$ to Sample 305-10-5, 120-122 cm). Undoubtedly these sediments represent only part of the middle Eocene.

The upper Eocene is characterized by rare Globigerapsis semiinvoluta, G. tropicalis, G. index, Globigerina corpulenta, G. galavisi, Hantkenina sp., and Globorotalia cerroazulensis (Sample 305-9-3, 97-99 $\mathrm{cm}$ to Sample 305-10-3, 47-49 cm).

In the Oligocene sediments, only the following can be tentatively outlined:

The lower part (within the Globigerina tapuriensis and Globigerina sellii Zones) contains $G$. officinalis, $G$. galavisi, G. prasaepis, G. pseudovenezuelana, Globigerinita unicava, G. pera, G. riveroae, Globorotaloides suteri, Globorotalia gemma, G. permicra, and very rare Globigerina ampliapertura and Pseudohastigerina sp. (Sample 305-8-3, 102-104 cm to Sample 305-9-2, 70-72 $\mathrm{cm})$.

The middle part (likely the Globigerina ampliapertura Zone) contains G. prasaepis, G. galavisi, Globigerinita unicava, G. pera, Globorotaloides suteri, Globorotalia gemma, and very rare Globigerina ampliapertura (Sample 305-8-1, 100-102 cm to Sample 305-8-2, 96-98 $\mathrm{cm})$.
The upper part (within the Globorotalia opima and Globigerina ciperoensis Zones) contains Globorotalia sp. aff. G. opima, G. nana, G. gemma, Globorotaloides suteri, Globigerina prasaepis, G. galavisi, and Globigerinita unicava (Sample 305-6-6, 118-120 cm to Sample 305-7-6, 50-52 cm).

The Oligocene is unconformably overlain by sediments of the lower Miocene Globigerinita dissimilis Zone (Sample 305-6-6, 30-32 cm).

It is noteworthy that at Site 306 , at the base of the southwest slope of Shatsky Rise (water depth $3399 \mathrm{~m}$ ), the Paleogene is entirely missing. Here, Lower to Upper Cretaceous (Albian-Cenomanian) deposits are directly overlain by Quaternary sediments.

\section{Mid-Pacific Mountains}

Paleogene deposits are penetrated by holes on opposite ends of this sublatitudinal range, on the west at Site 463, and on the east at Sites 44, 171, and 313.

At Site $463\left(21^{\circ} 21.01^{\prime} \mathrm{N}, 174^{\circ} 40.07^{\prime} \mathrm{E}\right.$; water depth $2525 \mathrm{~m}$ ), the Paleogene is composed of nannofossil oozes and foraminifer-nannofossil oozes of little thickness $(13 \mathrm{~m})$, with some interval hiatuses. The Paleogene rests with erosional unconformity on chalks of the middle Maastrichtian (Globotruncana gansseri Zone). The basal layers of the section are assigned to the Globorotalia palmerae Zone (= Acarinina pentacamerata Zone) of the lower Eocene. The rich assemblage of planktonic foraminifers consists of Globorotalia caucasica, G. aragonensis, G. quetra, Acarinina pentacamerata, A. aspensis, A. triplex, A. pseudotopilensis, A. broedermanni, Globigerina senni, G. pseudoeocaena, G. inaequispira, and Pseudohastigerina wilcoxensis (Sample 463-7-1, 135-137 cm to Sample 463-7-3, $10-12 \mathrm{~cm})$.

Higher in the section, following a gap, are sediments of the Globorotalia lehneri Zone (middle Eocene), with numerous Globigerapsis index, G. kugleri, Globigerinatheca barri, Truncorotaloides topilensis, T. rohri, Globorotalia spinulosa, Acarinina bullbrooki, and Globigerina senni, rarer Globorotalia lehneri, G. frontosa, and Globigerina pseudoeocaena, and very rare Acarinina rotundimarginata, Hantkenina sp. aff. $H$. alabamensis and Globorotalia aragonensis (Sample 463-6-6, 50-52 cm).

The Oligocene is also separated from the middle Eocene by a hiatus. Its lower part appears to be attributable to the Globigerina sellii Zone judging from the abundance of the index species, G. tripartita, G. tapuriensis, G. ouachitaensis, G. prasaepis, G. angustiumbilicata, G. turritilina, Cassigerinella chipolensis, Globorotalia gemma, G. permicra, and Chiloguembelina cubensis, with very rare specimens of Pseudohastigerina micra (Samples 463-6-4, 90-92 cm and 463-6-5, 90-92 $\mathrm{cm})$.

A similar assemblage of planktonic foraminifers was observed in overlying sediments as well, where Globigerina pseudovenezuelana, G. galavisi, Globigerinita unicava, Globorotalia nana, and rare Globigerina ampliapertura were identified. Representatives of Pseudohastigerina are missing here. This places the deposits in the Globigerina ampliapertura Zone (Sample 463-5-1, 
90-92 cm to Sample 463-6-3, 90-92 cm). The Oligocene is unconformably overlain by upper Miocene deposits.

Oligocene sediments contain abundant redeposited tests of planktonic foraminifers of the Upper Cretaceous, Paleocene (Globorotalia trinidadensis, Acarinina uncinata, Globorotalia pseudomenardii, and Globorotalia velascoensis Zones), lower Eocene (Globorotalia subbotinae, Globorotalia aragonensis, and Acarinina pentacamerata Zones), and middle Eocene. The section of Paleogene sediments in the vicinity of Site 463 appears to have been originally more complete stratigraphically, but many of its intervals have been removed by erosion.

Two holes (Sites 44 and 171) were drilled at Horizon Guyot, in the eastern Mid-Pacific Mountains. The Cretaceous/Paleogene contact was recovered in Hole 171 $\left(19^{\circ} 07.9^{\prime} \mathrm{N}, 169^{\circ} 27.6^{\prime} \mathrm{W}\right.$; water depth $\left.2290 \mathrm{~m}\right)$. The middle Eocene here unconformably overlies Upper Cretaceous deposits (Maastrichtian, Abathomphalus mayaroensis Zone). The Paleogene is composed of foraminifer-nannofossil ooze to nannofossil-foraminifer ooze, with chert intercalations at the base, and is about 95 meters thick. Sporadic sampling of cores prevents estimation of the continuity of the stratigraphic succession.

The middle Eocene begins with the Orbulinoides beckmanni Zone, with extremely rare specimens of the zonal species, accompanied by Acarinina bullbrooki, Truncorotaloides rohri, T. topilensis, Globigerapsis kugleri, G. index, Globigerinatheca barri, Globorotalia centralis, G. spinulosa, and Globigerina pseudovenezuelana (Sample 171-9-2, 30-32 cm to Sample 171-9-3, $120-122 \mathrm{~cm})$.

In the sediments of the overlying Truncorotaloides rohri Zone, the index species together with Globigerina pseudoeocaena compacta, G. pseudovenezuelana, Globigerapsis index, and Globorotalia spinulosa were found (Sample 171-8-3, 48-50 cm to Sample 171-8-6, $48-50 \mathrm{~cm}$ ). Middle Eocene sediments contain abundant redeposited foraminifers of the Upper Cretaceous, upper Paleocene (Globorotalia pseudomenardii and Globorotalia velascoensis Zones), and lower Eocene (Globorotalia subbotinae and Globorotalia formosa Zones).

The upper Eocene was not identified in Hole 171, probably because of poor recovery (an 8-m interval had no core at all). The base of the Oligocene is marked by the Ericsonia subdisticha Zone (Sample 171-7,CC); upward, there is a break in sampling (about $15 \mathrm{~m}$ ) which probably corresponds to the Globigerina tapuriensis and Globigerina sellii Zones. Above, the entire Oligocene zonal succession is established:

The Globigerina sellii Zone contains the index species, Globigerina tapuriensis, G. galavisi, G. tripartita, G. prasaepis, G. pseudovenezuelana, G. ouachitaensis, G. praebulloidoes, Globorotalia gemma, Chiloguembelina cubensis, and Pseudohastigerina barbadoensis (Sample 171-6-2, 125-127 cm).

The Globigerina ampliapertura Zone contains a similar assemblage of planktonic foraminifers, but without representatives of Pseudohastigerina (Sample 171-6-2, 34-36 cm).
The Globorotalia opima Zone contains abundant $G$. opima and G. nana, accompanied by G. gemma, Globigerina pseudovenezuelana, G. ciperoensis, G. angulisuturalis, G. angustiumbilicata, G. tripartita, G. sellii, G. galavisi, G. prasaepis, Globigerinita unicava, and Globorotaloides suteri (Sample 171-4-6, 52-54 cm to Sample 171-5-6, 52-54 cm).

The Globigerina ciperoensis Zone contains abundant, small $G$. ciperoensis, $G$. angustiumbilicata, and G. angulisuturalis, together with Globorotalia pseudokugleri, Globigerinita unicava, Globigerina tripartita, G. pseudovenezuelana, and Globorotaloides suteri (Sample 171-4-1, 52-54 cm to Sample 171-4-5, 52-54 cm).

Abundant redeposited Upper Cretaceous, Paleocene, lower Eoecene and (less frequently) middle Eocene planktonic foraminifers were found in the Oligocene sediments (particularly in the Globorotalia opima Zone).

Following a 9-meter break in core sampling, Oligocene sediments are succeeded by the lower Miocene Globigerinita dissimilis Zone (Sample 171-3-6, 50-52 cm).

At Site $44\left(19^{\circ} 18.5^{\prime} \mathrm{N}, 169^{\circ} 00.9^{\prime} \mathrm{W}\right.$; water depth $1478 \mathrm{~m}$ ) a similar succession of middle Eocene to Oligocene sediments was cored, although the contact with underlying deposits was not discovered. However, the upper Eocene is well represented there, and reworked Cretaceous and Paleocene foraminifers are absent, which permits more-distinct foraminifer zonation.

The middle Eocene is composed of nannofossil-foraminifer chalk with chert interbeds, whereas the upper Eocene and Oligocene comprise nannofossil-foraminifer chalk and ooze; thickness is about $\mathbf{4 0}$ meters.

Two zones were recognized in the middle Eocene:

The Orbulinoides beckmanni Zone contains numerous $O$. beckmanni, Globorotalia centralis, G. renzi, G. bolivariana, G. spinulosa, Globigerapsis index, G. kugleri, Globigerinatheca barri, Truncorotaloides rohri, T. topilensis, Globigerina pseudoeocaena compacta, and G. pseudovenezuelana, rarer Globorotalia frontosa, Globigerinita echinata, Acarinina rotundimarginata, and Pseudohastigerina micra, and extremely rare Hantkenina alabamensis, $H$. lehneri, and Globorotalia lehneri (Sample 44-4-5, 130-132 cm to Sample 44$4, \mathrm{CC})$,

The Truncorotaloides rohri Zone contains abundant T. rohi, Pseudohastigerina micra, Globorotalia centralis, Globigerina pseudoeocaena compacta, Globigerapsis index, and Chiloguembelina sp., accompanied by Truncorotaloides topilensis, Globorotalia renzi, G. spinulosa, Globigerinatheca barri, and rare Hantkenina alabamensis and Globorotaloides suteri. Hantkenina longispina, Globigerapsis tropicalis, Globorotalia cerroazulensis, and Globigerina posttriloculinoides appear here for the first time (Sample 44-3-5, 135-137 cm to Sample 44-4-4, 98-100 cm).

The upper Eocene is subdivided into two zones:

The Globigerapsis semiinvoluta Zone contains the index species, G. tropicalis, G. index, Globigerinatheca barri, Globorotalia cerroazulensis, G. centralis, Globigerina corpulenta, $G$. pseudovenezuelana, $G$. incretacea, G. pseudocorpulenta, G. praebulloides, G. tri- 
partita, Globigerinita howei, G. pera, Pseudohastigerina micra, Hantkenina suprasuturalis, and $H$. alabamensis (Sample 44-2-5, 140-142 cm to Sample 44-3-4, $40-42 \mathrm{~cm}$ ).

The Globorotalia cocoaensis Zone contains the same assemblage of planktonic foraminifers (except Globigerapsis semiinvoluta), together with typical Globorotalia cocoaensis and Cribrohantkenina inflata (44-2 (top) to Sample 44-2-4, 122-24 cm).

The upper Eocene/Oligocene relation is not clear (Core 1 is incomplete): presumably, they are separated by a small gap. In any case, the lowest part of the Oligocene belongs to the Globigerina sellii Zone, which is characterized by the index species, G. tapuriensis, $G$. tripartita, G. pseudovenezuelana, G. praebulloides, $G$. ampliapertura, G. angustiumbilicata, G. ouachitaensis, G. prasaepis, G. turritilina, Cassigerinella chipolensis, Globorotalia gemma, Globigerinita unicava, Pseudohastigerina barbadoensis, and P. micra (Sample 44-1-2, $30-35 \mathrm{~cm}$ to Sample 44-1,CC).

The youngest Oligocene sediments of Hole 44 belong to the Globigerina ampliapertura Zone, in which the index species is very common, but representatives of Pseudohastigerina are absent (44-1 (top) and Sample 44-1-1, 104-106 cm).

The age of overlying sediments is unknown here, because the upper 40 meters of the section were drilled without coring.

Site $313\left(20^{\circ} 10.52^{\prime} \mathrm{N}, 170^{\circ} 57.15^{\prime} \mathrm{W}\right.$; water depth $3484 \mathrm{~m}$ ) is north of Horizon Guyot, in a small basin surrounded by seamounts. Here the Paleogene is composed of deeper-water sediments than on Horizon Guyot. The middle Maastrichtian (Globotruncana gansseri Zone) and lower Eocene are separated by an interval $(9.5 \mathrm{~m})$ where sediments (hard layer) were not recovered. The lower and middle Eocene are represented by nannofossil chalk, foraminifer-nannofossil chalk, and radiolarian foraminifer-nannofossil chalk, with chert intercalations; the Oligocene consists of foraminifer-nannofossil ooze. The thickness of the Paleogene exceeds 150 meters. The deep-water character of the sediments is manifested by abundant radiolarians in the lower Eocene and by very strong dissolution of planktonic-foraminifer tests in the middle Eocene and Oligocene. Commonly the latter are represented by the most-resistant species, their fragments being numerous. In conjunction with the dissolution of planktonic foraminifers, sediments are enriched in benthic foraminifers.

Poor recovery and discontinuous coring do not permit tracing the entire succession of foraminifer zones, and only some were identified.

Planktonic-foraminifer assemblages are exceedingly rich in the lower part of the lower Eocene. The Globorotalia subbotinae Zone is characterized by numerous specimens of the index species, $G$. wilcoxensis, G. formosa gracilis, Acarinina nitida, A. pseudotopilensis, and $A$. soldadoensis, rarer $A$. camerata and $A$. triplex, and sporadic $A$. primitiva, A. esnaensis, and Globorotalia aequa. In the upper part of the zone, specimens of Globorotalia marginodentata are common. Globigerinids (Globigerina compressaformis, and G. nana) are very sporadic. It is interesting to note that shells of some species of Acarinina on their spiral side (along the spiral suture) have additional openings resembling additional apertures of the genus Truncorotaloides (Sample $313-12-5,52-54 \mathrm{~cm}$ to Sample 313-13-6, 118-120 cm).

Sediments in the interval from Sample 313-12-1, 135$137 \mathrm{~cm}$ to Sample 313-12-4, 52-54 cm apparently have to be assigned to the Globorotalia formosa formosa Zone. The planktonic-foraminifer assemblage is similar to that of underlying sediments, but contains rare Globorotalia sp. aff. G. formosa formosa, G. lensiformis, and G. quetra, and common G. marginodentata.

Data on the upper part of the lower Eocene are scarce, because of poor recovery; from an interval of about 20 meters, only 0.5 meters of sediments were obtained, with abundant radiolarians and sporadic Globorotalia aragonensis, Acarinina pentacamerata, $A$. interposita, $A$. pseudotopilensis, and $A$. soldadoensis (Sample 313-9-1, 127-129 cm). These sediments are assignable to the undifferentiated Globorotalia aragonensis and Globorotalia palmerae Zones.

The lower and middle Eocene are also separated by an interval $(9.5 \mathrm{~m})$ without recovery. Perhaps this explains why the basal middle Eocene belongs to the Globorotalia lehneri Zone, with extremely rare specimens of the index species and more common Acarinina bullbrooki, A. rotundimarginata, Truncorotaloides rohri, T. topilensis, Globigerapsis index, G. kugleri, Globigerinatheca barri, Globorotalia spinulosa, G. frontosa, Globigerina senni, and Globorotaloides carcoselleensis (Sample 313-7-2, 70-72 cm to Sample 313-7-6, 130-132 $\mathrm{cm})$. This microfauna is accompanied by abundant redeposited planktonic foraminifers of the Upper Cretaceous, upper Paleocene (Globorotalia pseudomenardii and Globorotalia velascoensis Zones), and lower Eocene (Globorotalia aragonensis Zone). Usually the reworked foraminifers are very well sorted and well preserved, whereas the in situ middle Eocene planktonic foraminifers bear traces of strong selective dissolution, especially the planktonic foraminifers from the upper part of the middle Eocene (Sample 313-5-1, 125-127 cm to Sample $313-6-1,130-132 \mathrm{~cm}$ ), where only sporadic specimens of Globigerina senni, Globigerapsis index, Acarinina bullbrooki, and Globorotaloides carcoselleensis were encountered (together with benthic foraminifers and abundant redeposited Upper Cretaceous, upper Paleocene and lower Eocene planktonic foraminifers).

The middle Eocene and Oligocene are separated by a hiatus which presumably corresponds to the upper Eocene. The Oligocene is characterized by impoverished assemblages of planktonic foraminifers bearing distinct traces of selective dissolution, but divisible into the following zones:

The Globigerina ampliapertura Zone contains rare specimens of the index species and more abundant frequent G. prasaepis, G. tripartita, G. pseudovenezuelana, G. angustiumbilicata, G. pseudoampliapertura, G. sellii, G. tapuriensis, Globigerinita unicava, G. riveroae, G. pera, Globorotaloides suteri, Globorotalia gemma, G. nana, and G. clemenciae (Sample 313-4-2, 20-22 
cm to Sample 313-5-1, 20-22 cm). Reworked Upper Cretaceous planktonic foraminifers are not numerous here.

In the Globorotalia opima Zone, specimens of the index species are mainly present as the most resistant to the dissolution. Other species are extremely rare: Globigerina prasaepis, G. tripartita, Globigerinita unicava, Globorotaloides suteri (Sample 313-3-2, 50-52 cm to Sample 313-3-6, 117-119 cm).

The Globigerina ciperoensis Zone contains rare $G$. venezuelana, G. sellii, G. prasaepis, and Globigerinita unicava (Sample 313-3-1, 70-72 cm). This zone is determined conditionally, because of the absence of Globorotalia opima.

Upward, following an interval of 28.5 meters without recovery, middle Miocene sediments are identified.

\section{MAIN FEATURES OF PALEOGENE STRATIGRAPHY OF THE NORTHWESTERN PACIFIC, BASED ON PLANKTONIC FORAMINIFERS}

Figure 1, which summarizes data of the preceding text, shows that complete sections of Paleocene calcareous sediments are absent in the northwest Pacific. Only Site 465 (Hess Rise) and Sites 47 and 305 (Shatsky Rise) display complete or almost complete sections of the Paleocene and lower Eocene. For the upper part of the middle Eocene, upper Eocene, and Oligocene, the most important sites are 44 and 171 (Horizon Guyot). Thus, only a combination of all sites permits reconstruction of the characteristics of the planktonic foraminifer faunas and the zonal stratigraphy of the Paleogene.

Most of the sites, including those of Leg 62, are between 19 and $36^{\circ}$ north latitude, i.e., within modern tropical-subtropical climatic belts; Site 192 is an exception, well to the north $\left(53^{\circ}\right)$. Naturally, the Paleogene planktonic-foraminifer assemblages bear a tropical character. In the Paleocene and lower and middle Eocene, keeled Globorotalia, the genera Truncorotaloides and Orbulinoides, and various species of Globigerapsis and Globigerinatheca are widely developed. The upper Eocene is characterized by Globigerapsis semiinvoluta, Cribrohantkenina, and the Globorotalia cerroazulensis group; large Globigerina are abundant in the Oligocene. In contrast, in the Paleocene and lower and middle Eocene, representatives of Acarinina and Globigerina are subordinate. In the middle and upper Eocene, some species of Globigerina and Hantkenina which are typical of contemporaneous sediments of subtropical and temperate belts are rare. Acarinina species are numerous in sediments of the Acarinina uncinata and Globorotalia palmerae Zones of Sites 47, 305, and 465. Nevertheless, planktonic-foraminifer assemblages of these zones have a definitely tropical character and differ strongly from those developed in synchronous sediments of the subtropical-temperate belts; in the latter case, Globigerina species dominate in the Acarinina uncinata Zone, and in the Globorotalia palmerae Zone they constitute an essential component of planktonic assemblages. At Site 313, some specimens of lower Eocene Acarinina pseudotopilensis, A. nitida, A. prim- itiva, and $A$. interposita possess additional apertural openings on the spiral side of tests, a feature apparently typical of tropical forms of Acarinina (Krasheninnikov and Hoskins, 1973). All these data testify that calcareous sediments of Hess Rise, Shatsky Rise, and, most of all, the Mid-Pacific Mountains were formed in some southern areas closer to the equatorial belt, and subsequently were shifted to the north-northwest as a result of motion of the Pacific Plate, as suggested by many scientists (e.g., Lancelot and Larson, 1975).

Typical subtropical and temperate faunas of planktonic foraminifers are now very well studied in the countries of the Mediterranean Sea, Central Europe, and southern regions of the U.S.S.R. (Crimea, Caucasus, Transcaspian), and also in the North Atlantic, i.e., Bay of Biscay and Rockall Plateau (Berggren, 1972; Krasheninnikov, 1979). Unfortunately, in the northwest sector of the Pacific Ocean they are still unknown, because between 36 and $53^{\circ}$ north latitude there is an insufficient number of holes that penetrated calcareous sediments of the Paleogene. The paleoclimatological significance of Paleogene planktonic foraminifers at Site 192 is difficult to interpret; their impoverishment and poor preservation is likely the result of selective dissolution. Paleogene shallow-water carbonate sediments with rare planktonic foraminifers were discovered on Leg 55 at Suiko (Site 433), Nintoku (Site 432), and Ojin (Site 430) Seamounts (Emperor Seamounts chain), but studies of these materials have not yet been published. When the bands of Paleogene calcareous sediments with tropical, subtropical, and temperate planktonic-foraminifer assemblages have been delineated, it will be possible to give a more-detailed paleoclimatological reconstruction of Paleogene time, and to outline with more precision stages of motion of the Pacific Plate to the northwest.

Determination of the paleoclimatic affinity of planktonic-foraminifer assemblages is complicated by selective dissolution, which hampers identification. Certainly, Paleogene calcareous sediments at all sites under consideration were formed above the CCD, but sediments of some sites were deposited below the foraminifer lysocline.

Sedimentation of pelagic nannofossil-foraminifer ooze took place above the foraminifer lysocline during the Paleocene to early Eocene at Site 47, the middle to late Eocene and Oligocene at Site 44, the Paleocene at Site 465 , the early to middle Eocene and Oligocene at Site 463, and the middle Eocene and Oligocene at Site 171 (modern water depths 1500-2700 m). In each case, planktonic foraminifers are characterized by high species diversity and excellent preservation.

Precipitation of foraminifer-nannofossil ooze below the foraminifer lysocline took place during the early to middle Eocene and Oligocene at Site 310, the Paleocene, Eocene, and Oligocene at Site 305 , and the early to middle Eocene and Oligocene at Site 313 (modern water depths 2900-3500 m). During the middle to late Eocene at Site 466 (modern water depth $2665 \mathrm{~m}$ ), sedimentation took place at or near the foraminifer lysocline. Planktonic-foraminifer assemblages at these sites are distinguished by the following characteristics: low diversity; 


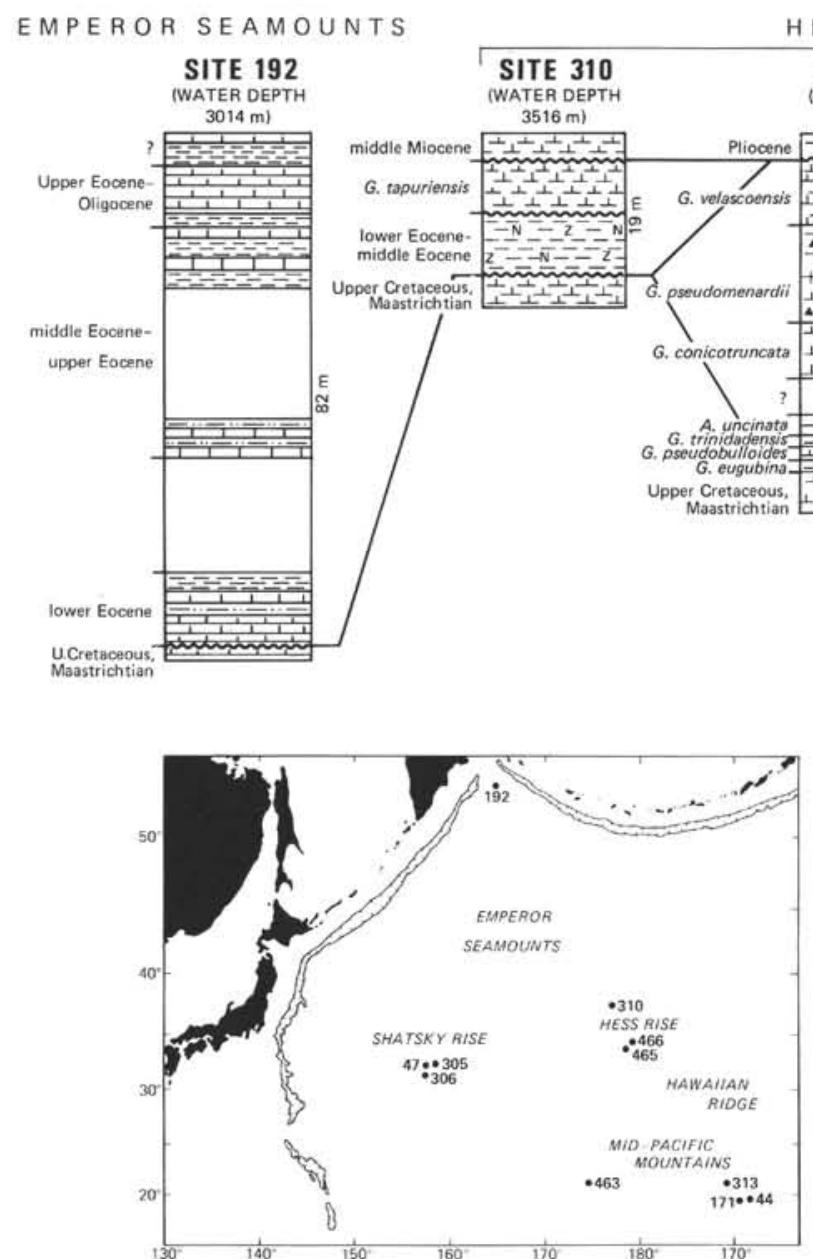

HESS RISE

\section{SITE 465}

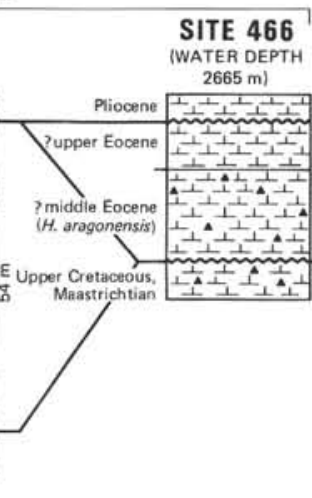

SHATSKY RISE

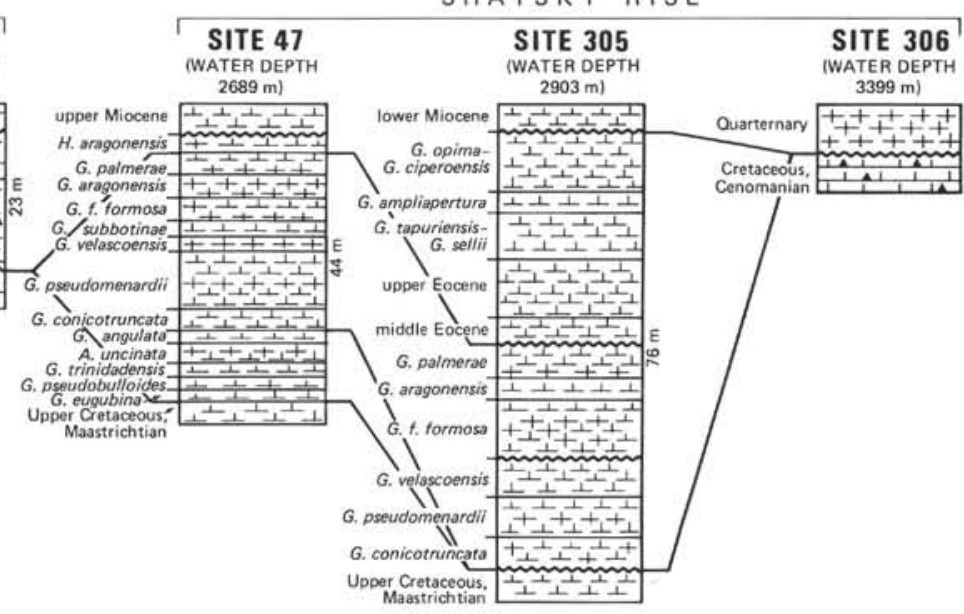

306 (26) $1065 \mathrm{~m}$ )

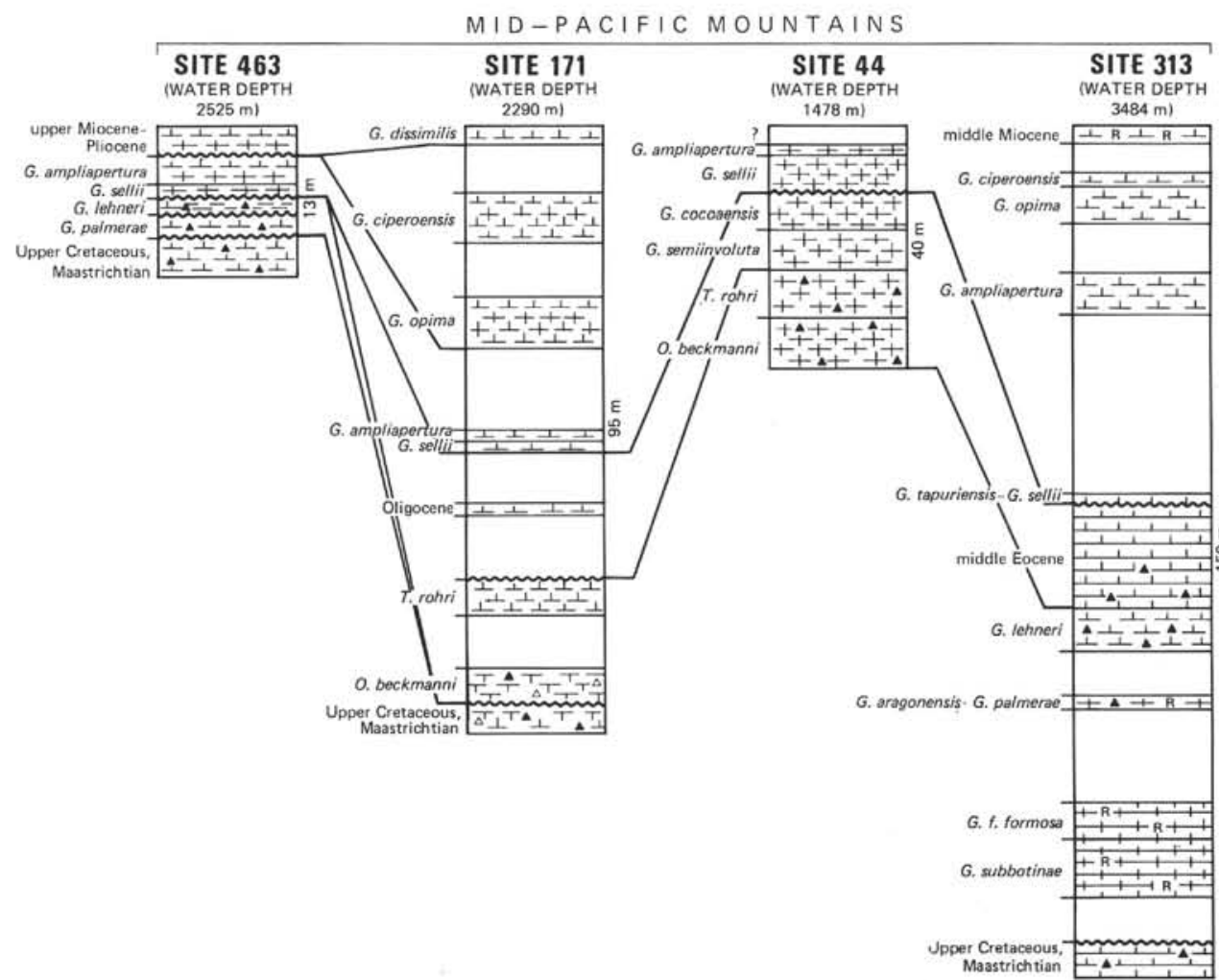

卉 Limeston

$==$ A clay and claystone

E- Silty clay and claystone

Z Zeolitic nannofossil clay

$\because \therefore$ chert

Uncored intervals

Discontormities

Jpper Cretaceous,
Masstrichtian

Figure 1. Sections of Paleogene sediments of the Emperor Seamounts, Hess Rise, Shatsky Rise, and Mid-Pacific Mountains. 
absence of some easily dissolved species; enrichment of sediments in the most-resistant species, i.e., Acarinina spp., Globigerina senni, G. pseudoeocaena, G. prasaepis, G. pseudovenezuelana, G. sellii, Globigerapsis index, Globorotalia frontosa, G. nana, G. opima, Globigerinita unicava, G. pera, Globorotaloides suteri, etc.; etched shell surfaces; abundant shell debris; enrichment of the microfauna in benthic foraminifers. These assemblages reflect only in part their original composition.

In the upper Paleocene, dissolution is pronounced (Site 305); in the lower Eocene it is weak, and planktonic-foraminifer assemblages are rather rich (Sites 305, $313)$; very strong dissolution is evident in the middle and upper Eocene (Sites 310, 466, 305, 313); in the Oligocene it is again somewhat weaker (Sites $310,305,313$ ). Such variations of selective dissolution reflect oceanic subsidence, the rise of the foraminifer lysocline in accordance with removal of the Pacific Plate from the equatorial belt, and fluctuations of the lysocline during Paleogene time.

Above all, we must consider the appearance and existence of resistant planktonic microfauna on the whole. Deterioration of climate in Oligocene time might have caused the distinct climatic differentiation of distribution of planktonic foraminifers, but assemblages with comparatively low species diversity and weak specialization do not yield as perfect a biogeographic picture as in the Eocene. They testify to a certain uniformity of Oligocene planktonic foraminifers, because even their assemblages from the temperate belt (North Atlantic: Bay of Biscay and Rockall Plateau) are essentially similar to more-southern assemblages. We may suggest that Oligocene planktonic foraminifers in general were more tolerant both to climatic conditions and to selective dissolution. Without doubt, careful estimation of the influence of dissolution on the composition of planktonic-foraminifer assemblages will help avoid mistakes in determining their paleoclimatic peculiarities.

Insofar as Paleogene planktonic foraminifers of the Mid-Pacific Mountains, Shatsky Rise, and Hess Rise bear a distinctly tropical character, the zonal scheme of Bolli (1957 a, b), with some subsequent modifications (Blow, 1969; Premoli-Silva and Bolli, 1973) can be applied to the Paleogene sediments.

In the Paleocene the following zones were identified: Globigerina eugubina (Sites 47, 465), Globorotalia pseudobulloides (Sites 47, 465), Globorotalia trinidadensis (Sites 47, 465), Acarinina uncinata (Sites 47, 465), Globorotalia angulata (Site 47), Globorotalia conicotruncata (Sites 47, 305, 465), Globorotalia pseudomenardii (Sites 47, 305, 465), Globorotalia velascoensis (Sites 47, 305, 465).

The lower Eocene contains these zones: Globorotalia subbotinae (Sites 47, 313), Globorotalia formosa formosa (Sites 47, 305, 313), Globorotalia aragonensis (Sites 47, 305), Globorotalia palmerae (Sites 47, 305, 463).

The middle Eocene contains these zones: Hantkenina aragonensis in the broad sense (Sites 47, 466), Globorotalia lehneri (Sites 313, 463), Orbulinoides beckmanni
(Sites 44, 171), Truncorotaloides rohri (Sites 44, 171).

The upper Eocene contains these zones: Globigerapsis semiinvoluta (Site 44), Globorotalia cocoaensis (Site 44).

The Oligocene includes these zones: Globigerina tapuriensis (Site 310), Globigerina sellii (Sites 44, 171, 463), Globigerina ampliapertura (Sites 44, 171, 305, 313,463 ), Globorotalia opima (Sites 171, 313), Globigerina ciperoensis (Sites 171, 313).

Hence, only two zones have not been identified: the Globigerapsis kugleri Zone in the middle Eocene, and the Globigerina gortanii-Globorotalia centralis Zone at the top of the upper Eocene. Their absence appears to be related to gaps in the sedimentary record, dissolution effects, and poor recovery.

The most important feature of the regional stratigraphy of the Paleogene deposits of the northwest Pacific is heterogeneity of sections of calcareous sediments on the elevations (Emperor Seamounts, Shatsky Rise, Hess Rise, Mid-Pacific Mountains) (Fig. 1). For example, on Hess Rise at Site 465 there is a continuous Paleocene section, but the Eocene and Oligocene are missing. At neighboring Sites 310 and 466, the Paleocene is absent, but the Eocene and Oligocene are represented by some intervals. On Shatsky Rise at Site 47, the Paleocene and lower Eocene are very well developed, but the middle to upper Eocene and Oligocene are not present. At Site 305, the basal Paleocene and basal lower Eocene are missing, but the middle to upper Eocene, and especially the Oligocene, are well represented. At Sites 48 and 306, the Paleogene is entirely lacking. On the Mid-Pacific Mountains, the Paleocene is missing, and the basal parts of sections are composed of sediments of the lowermost lower Eocene (Site 313), uppermost lower Eocene (Site 463), and upper middle Eocene (Site 171). At Site 463, only some intervals of the middle Eocene and Oligocene were encountered, whereas at Sites 171, 44, and 313, sections of the middle to upper Eocene and Oligocene are comparatively complete.

Certainly the inconstant and changeable nature of the Paleogene sedimentary cover on the various elevations lays an imprint on the Paleogene stratigraphy of the whole realm. Nevertheless, there are hiatuses which can be traced rather constantly within the area in question.

At all sites except 47 and 465 , the Mesozoic and Cenozoic are separated by a gap. The Upper Cretaceous is overlain by sediments of the middle Paleocene (Globorotalia conicotruncata Zone, Site 305); lower Eocene (Globorotalia subbotinae Zone, Site 313; Globorotalia palmerae Zone, Site 463); middle Eocene (Hantkenina aragonensis Zone, Site 466; Orbulinoides beckmanni Zone, Site 171). Thus, this hiatus does not represent a narrow stratigraphic interval (not equivalent, for instance, to the Maastrichtian/Danian boundary). In general, it corresponds to the interval from the base of the Paleocene to the middle middle Eocene. At Site 48, the Maastrichtian is overlain by the upper Miocene, and at Site $\mathbf{3 0 6}$ by the Quaternary.

There are scanty data on the character of the Paleocene/Eocene relation-at Site 47 the contact is gradual, at Site $\mathbf{3 0 5}$ it is disconformable. 
The middle Eocene is separated from underlying sediments by a hiatus as a rule; it rests on Maastrichtian (Sites 310, 466, 171) and lower Eocene (Sites 305, 463) sediments. Only at Site 47 is the contact conformable.

The upper Eocene is recognized reliably only at Sites 44 and 305 , where it passes into the middle Eocene by a gradual transition.

The Oligocene is separated by a gap from the middle Eocene (Sites 310, 463, 313) or upper Eocene (Site 44). The normal upper Eocene/Oligocene contact is observed only at Site 305 .

A gradual transition from Oligocene to Miocene is suggested only at Site 171 . At all other sites, there is a hiatus, but again it does not represent a narrow stratigraphic interval (not upper Oligocene to lower Miocene, for example). This gap separates different subdivisions of the Paleogene and Neogene: lower Miocene and upper Oligocene (Site 305); middle Miocene and upper Oligocene (Site 313) or lower Oligocene (Site 310); upper Miocene and lower Oligocene (Site 463) or middle Eocene (Site 47); Pliocene and upper Eocene (Site 466) or Paleocene (Site 465).

The nature of these gaps can be clarified if the distribution of reworked planktonic foraminifers and, especially, calcareous turbidites is analyzed. Redeposited planktonic foraminifers and turbidites have not been found in Paleogene sediments of Sites 192, 44, 47, 465, and 310 (although the condensed Paleogene section of Site 310 contains some hiatuses). At Site 305, sediments of the Globorotalia conicotruncata Zone includes pieces of nannofossil ooze with planktonic-foraminifer assemblages belonging to older zones of the Paleocene (Globorotalia angulata, Acarinina uncinata, and Globorotalia trinidadensis Zones).

Turbidites are well developed at Sites 171, 463, 313, and 466 , where they alternate with normal pelagic sediments. At Site 171, the middle Eocene contains abundant planktonic foraminifers from the Upper Cretaceous and from some intervals of the upper Paleocene and lower Eocene. The Oligocene at Site 171 contains species reworked from the Upper Cretaceous, upper Paleocene, and lower and middle Eocene. At Site 463, the lower and middle Eocene are without turbidites, but the Oligocene contains a mass accumulation of foraminifers redeposited from the Upper Cretaceous, upper Paleocene, and lower and middle Eocene. At Site 313, the lower Eocene is marked by ooze, whereas the middle Eocene is marked by turbidites with abundant planktonic foraminifers reworked from the Upper Cretaceous and all zones of the upper Paleocene and lower Eocene; at this site the Oligocene is again represented by pure pelagic ooze. At Site 466, middle Eocene sediments contain common reworked foraminifers from the upper Cretaceous and lower Eocene. The upper Eocene does not contain redeposited microfaunas; the basal layers of the Neogene include abundant foraminifers redeposited from the upper Cretaceous, lower and middle Eocene, and Oligocene.

Thus, the Paleogene sections at Hess Rise, Shatsky Rise, and the Mid-Pacific mountains (or at least neighboring sections) have been at one time much more com- plete stratigraphically than they are now. In the area of Site 305 , it is necessary to admit the primary existence of lower Paleocene sediments (including the Danian Stage); in the region of Site 171 sediments of the upper Paleocene, lower Eocene, and lower middle Eocene originally existed; in the area of Site 463, sediments of the upper Paleocene, and some zones of the lower and middle Eocene were present; in the vicinity of Site 313, sediments of the upper Paleocene and all zones of the lower Eocene existed; near Site 466, sediments of the upper Paleocene, lower and middle Eocene, and Oligocene were present. In these areas, primary hiatuses corresponded to more narrow stratigraphic intervals. The universal distribution of a reworked upper Paleocene microfauna (Globorotalia pseudomenardii and Globorotalia velascoensis Zones) may indicate that the gap between Mesozoic and Cenozoic is confined to the lower Paleocene.

Analysis of hiatuses and foraminifer assemblages of turbidities allows the conclusion that the gaps mainly represent repeated erosion of sediments, not non-deposition. This submarine erosion apparently has resulted from a combination of general causes (eustatic fluctuations of sea level, paleogeographic variations, and changes in bottom currents) and local causes (slides of unconsolidated sediments, turbidity currents off highs, etc.). It is probable that intensification of erosion on rises of the northwest Pacific at the Cretaceous/Paleogene boundary, in the middle Eocene, in the Oligocene, and at the Oligocene/Neogene boundary reflects a phenomenon of general rank. The comparatively small number of sites in this realm of the Pacific Ocean permits for the present only preliminary conclusions.

The peculiarities of the regional stratigraphy of $\mathrm{Pa}-$ leogene calcareous sediments on the Mid-Pacific Mountains, Shatsky Rise, and Hess Rise-numerous breaks in sedimentation, turbidites, dissolution facies, etc.-is compelling evidence that the thickness of sediments as an indication of biological productivity and the paleogeography of a given region must be used with care.

\section{ACKNOWLEDGMENTS}

We express our sincere gratitude to the Co-Chief Scientists of DSDP Leg 62, Dr. J. Thiede (Universitetet i Oslo, Blindern, Oslo, Norway) and Dr. T. Vallier (U.S. Geological Survey, Menlo Park, California, U.S.A.) for the opportunity of obtaining materials of this leg for publication. Samples of material from Legs 17, 19, and 32 were supplied through the assistance of the U.S. National Science Foundation and Deep Sea Drilling Project (Scripps Institution of Oceanography, San Diego), to whom we also express our gratitude. I would like to thank Dr. T. P. Bondareva (Geological Institute of the U.S.S.R. Academy of Sciences, Moscow) and Dr. I. A. Basov (Institute of Lithosphere of the U.S.S.R. Academy of Sciences, Moscow), who have read the manuscript and given much good advice. John Usher (Scripps Institution of Oceanography) assisted in copy editing the original manuscript, for which I am most grateful.

\section{REFERENCES}

Berggren, W. A., 1972. Cenozoic biostraigraphy and paleobiogeography of the North Atlantic. In Laughton, A. S., Berggren, W. A., et al., Init. Repts. DSDP, 12: Washington (U.S. Govt. Printing Office), 965-1001.

Blow, W. H., 1969. Late middle Eocene to recent planktonic foraminiferal biostratigraphy. In Brill, E. J. (Ed.), Proceedings of the First 
International Conference on Planktonic Microfossils, Geneva, 1967: Leiden (E. J. Brill), pp. 199-422.

Bolli, H. M., 1957a. The genera Globigerina and Globorotalia in the Paleocene-lower Eocene Lizard Springs formation of Trinidad, B.W.I. Bull. U.S. Nat. Mus., 215:61-81.

1957b. Planktonic Foraminifera from the Eocene Navet and San Fernando formations of Trinidad, B.W.I. Bull. U.S. Nat. Mus., 215:155-172.

1957c. Planktonic Foraminifera from the Oligocene-Miocene Cipero and Lengua formations of Trinidad, B.W.I. Bull. U.S. Nat. Mus., 215:97-123.

Douglas, R. C., 1973. Planktonic foraminiferal biostratigraphy in the central north Pacific Ocean. In Winterer, E. L., Ewing, J. I., et al., Init. Repts. DSDP, 17: Washington (U.S. Govt. Printing Office), 673-694.

Echols, D. G., 1973. Foraminifera, Leg 19, Deep Sea Drilling Project. In Creager, J. S., Scholl, D. W., et al., Init. Repts. DSDP, 19: Washington (U.S. Govt. Printing Office), 721-735.

Fleisher, R. L., 1975. Oligocene planktonic foraminiferal biostratigraphy, central north Pacific Ocean, Deep Sea Drilling Project, Leg 32. In Larson, R. L., Moberly, R., et al., Init. Repts. DSDP, 32: Washington (U.S. Govt. Printing Office), 753-763.

Hofker, J., 1978. Analysis of a large succession of samples through the upper Maastrichtian and the lower Tertiary of drill hole 47.2, Shatsky Rise, Pacific, DSDP. J. Foram. Res., 8(1):46-75.

Krasheninnikov, V. A., 1971a. Cenozoic foraminifera. In Fischer, A. G., Heezen, B. C., et al., Init. Repts. DSDP, 6: Washington (U.S. Govt. Printing Office), 1055-1068.

, 1971b. Stratigraphy and foraminifera of Cenozoic pelagic sediments of the Pacific northwestern part (based on materials of
Deep Sea Drilling). Questions Micropaleont., 14:140-199. [in Russian]

1979. Stratigraphy and planktonic foraminifers of Cenozoic deposits of the Bay of Biscay and Rockall plateau, DSDP, Leg 48. In Montadert, L., Roberts, D. G., et al., Init. Repts. DSDP, 48: Washington (U.S. Govt. Printing Office), 431-450.

Krasheninnikov, V. A., and Hoskins, R. H., 1973. Late Cretaceous, Paleogene and Neogene planktonic foraminifera. In Heezen, B. C., MacGregor, I. D., et al., Init. Repts. DSDP, 20: Washington (U.S. Govt. Printing Office), 105-203.

Lancelot, Y., and Larson, R. L., 1975. Sedimentary and tectonic evolution of northwestern Pacific. In Larson, R. L., Moberly, R., et al., Init. Repts. DSDP, 32: Washington (U.S. Govt. Printing Office), 925-939.

Luterbacher, H. P., 1975. Paleocene and early Eocene planktonic foraminifera, Leg 32, Deep Sea Drilling Project. In Larson, R. L., Moberly, R., et al., Init. Repts. DSDP, 32: Washington (U.S. Govt. Printing Office), 725-733.

Premoli-Silva, I., and Bolli, H. M., 1973. Late Cretaceous to Eocene planktonic foraminifera and stratigraphy of the Leg 15 sites in the Caribbean Sea. In Edgar, N. T., Saunders, J. B., et al., Init. Repts. DSDP, 15: Washington (U.S. Govt. Printing Office), 499-547.

Toumarkine, M., 1975. Middle and late Eocene planktonic foraminifera from the northwestern Pacific, Leg 32 of DSDP. In Larson, R. L., Moberly, R., et al., Init. Repts. DSDP, 32: Washington (U.S. Govt. Printing Office), 735-751. 